\title{
From glutton to gourmet: is gourmandise still a deadly sin?
}

\author{
Gilles Petit
}

\author{
Gilles is a recent Master of \\ Gastronomy graduate from \\ Auckland University of \\ Technology. He holds the role \\ of senior lecturer in culinary \\ arts (pâtisserie) at the School \\ of Hospitality and Tourism \\ where he lectures on the first \\ year of the Diploma in \\ Pâtisserie. His research \\ interests include the wider \\ field of pâtisserie, recently \\ looking at the historical \\ importance of French \\ gastronomy in the culinary \\ arts.
}

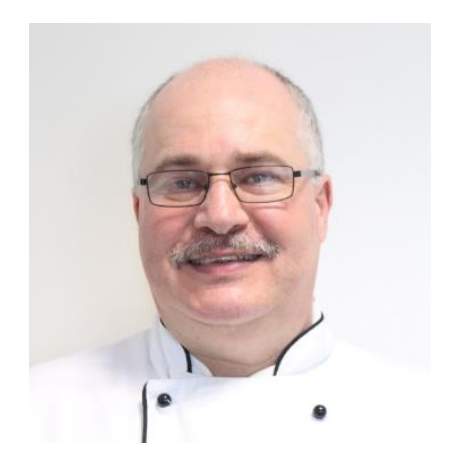

Drawing from historical literary works and contemporary French literature, this study [1] explored the evolution of the meanings of 'gourmandise' as a concept, from its early characterisation as a cardinal sin to a contemporary notion merging with visual textualisation. Furthermore, it argues that the twentieth century paved the way for a transformation in the meaning of gourmandise: its definition now emphasises a visual refinement characteristic, while retaining the element of excess as part of its appeal, thus making 'gourmandise' symbolic, accessible and acceptable to the general public.

Although the word 'gourmandise' appeared in written documents at the end of the Middle Ages, its history is much older since its use dates back to the early days of Christianity, to the first monastic communities of the third and fourth centuries. In addition, while the term still exists today, its significance has had many variations over the centuries.

While contemporary lexicographers define it as "the aptitude to appreciate the quality and delicacy of dishes" and the "excessive taste for the pleasure of the table" [2], its meaning has varied over the centuries [3] and is still contested. Philosophical, spiritual and social debates exist over whether the word depicts excess or moderation.

In Western society, gourmandise refers to three denotations roughly corresponding to three historical periods. The earliest meaning refers to the big eaters, the heavy drinkers, and all the excesses of the table. Strongly negative, the word 'gourmandise' qualifies a horrible vice, one of the seven deadly sins codified by the Christian Church.

Gradually, gourmandise was enriched by a second, positive sense, which would triumph in France in the seventeenth and eighteenth centuries and introduce the word 'gourmet' into European languages. While still reprobated by the Christian Church and moralists, gourmandise became a respectable epithet characterising amateur appreciators of good food, good wines and good company.

The eighteenth century brought about a redefinition of the notion of gourmandise, all the more so as the influence of the Christian Church declined considerably. The works of Grimod de la Reynière and, a few years later, Brillat-Savarin saw a semantic change in the meaning of gourmandise, which 
has been attributed to the transition of an economy of scarcity to one of abundance $[4,5]$.

The twentieth and twenty-first centuries brought a new era for gourmandise. With the advent of digital communication, people began to talk about their experiences more rapidly and to a wider audience. Eating out has become a social event, one which must be shared instantly. Gourmandise has become digital and focuses both on quality and quantity, retaining some of its original meaning but with a new visual dimension [5].

Gourmandise is now part of everyday and professional life. It still includes the implications of excess, sharing and exchange, but now denotes transference in an increasingly seductive and interactive way. This rediscovered gourmandise is now voyeuristic instead of the gourmandise of the stomach.

The findings of this study suggest that, while the meaning of gourmandise has evolved over a period of two millennia, the aspect of excessive food consumption has been retained from its beginnings right through to the twenty-first century. Paralleling its growing prestige within popular culture and social media, the discourse on gourmandise is thriving. Amidst the 'explosion' of food-related blogs, vlogs, websites and television programmes, gourmandise has become an engaging form of entertainment, trying to satisfy the appetites of a contemporary 'food-crazed' culture.

The original research on which this article is based is available here http://hdl.handle.net/10292/12964

\section{Corresponding author}

Gilles Petit can be contacted at: gilles.petit@aut.ac.nz

\section{References}

(1) Petit, G. From Glutton to Gourmet: Is Gourmandise Still a Deadly Sin? Master's Thesis, Auckland University of Technology, Jul 2019. http://hdl.handle.net/10292/12964 (accessed Apr 20, 2020).

(2) Gourmandise. Dictionnaire de l'Académie Française [online], 9th ed. https://academie.atilf.fr/consulter/Gourmandise?page=1 (accessed May, 2018).

(3) Bantreil-Voisin, N. Gourmandise: Histoire d'un péché capital [online]. La Cliothèque, Jan 3, 2011. http://clio-cr.clionautes.org/gourmandise-histoire-d-un-peche-capital.html (accessed May 1, 2016).

(4) Meyzie, P., Ed. La gourmandise entre péché et plaisir. Lumières 2008, 11. https://www.fabula.org/actualites/lumieres-ndeg11-la-gourmandise-entre-peche-etplaisir 28260.php (accessed April, 2018).

(5) Greene, C. Gourmands \& Gluttons: The Rhetoric of Food Excess; Peter Lang Publishing: New York, 2015. 